\title{
Empal Gentong and Culinary Culture
}

\author{
Rudy Harjanto ${ }^{1 *}$, Setya Ambar Pertiwi ${ }^{2}$ \\ ${ }^{1}$ Post-Graduate Studies, Universitas Prof. Dr. Moestopo (Beragama), Jakarta - 10270, Indonesia \\ ${ }^{2}$ Faculty of Social and Political Sciences, Universitas Prof. Dr. Moestopo (Beragama), Jakarta - 10270, Indonesia \\ "Corresponding author. Email: abrudyharjanto@gmail.com
}

\begin{abstract}
Food is the backbone of many traditions. Food combined together with culture are inter-related, mapping identities, origins, and what is experienced by society at any given moment. The culture of Cirebon as a coastalcity environment deserves to have the food that has a peculiarity of the beach, such as fish and its relatedproducts. However, the popular food is based on and processed from beef such as empal gentong that becomes more famous than the fish-food products. The article looks upon the relations of culinary culture to the current gastronomy trends in Cirebon.
\end{abstract}

Keywords: Cirebon, empal gentong, culinary culture, gastronomy

\section{INTRODUCTION}

City of Cirebon is the main city at the border of the northern coast of Java Island, which is the hub of transportation mobility between West Java and Central Java. It is located in a coastal area which has a wide-plain area and can be reached by road as far as $130 \mathrm{~km}$ from the city of Bandung and $258 \mathrm{~km}$ from the city of Jakarta. Located at the border of West Java, which has a Sundanese culture and Central Java, which has a Javanese culture, Cirebon has been a meeting point for Javanese and Sundanese cultures since several centuries ago. The native Cirebon people (Cirebonese) usually speak two languages, Sundanese and Javanese, and many Cirebon residents speak a dialect which is a mixture of both.

According to some sources, the city of Cirebon is thought to have originated from the word Caruban, in Sundanese which means mixture or it could also come from the word $\mathrm{Ci}$ which means water or river and Rebon which means Rebon shrimp (Acetes), a type of shrimp that is small in size and lives in Southeast Asian waters. Indeed, the main product as a city on the coast is fish, including shrimp. Shrimp is one of the fishery products of Cirebon City. Cirebon as a coastal city is thought to be influenced by and blends various cultures that come and form its own characteristics. This mixed-culture includes the elements of Sundanese, Javanese, Chinese, and Arabic culture which can be seen from several typical performances of Cirebon people, including Tarling and Cirebon Mask Dance. The handicrafts include Cirebon wooden-masks, glass painting, and batik. Batik from Cirebon has a unique characteristic, namely the Mega Mendung motive, which is a motive shaped like a lumpy cloud that usually forms a frame in the main image. From a gastronomic point of view, Cirebon has several specialties including: Sega Jamblang, Sega Lengko, Tofu Gejrot, and Empal Barrel.

[1] stated that empal is often perceived as beef and so on, which after being seasoned and boiled, cut slightly flat, made tender by beating the meat and then fried. However, it turns out that the typical Cirebon Empal Gentong is different, in which the empal here is a variation of a soup like curry, which is cooked with firewood in a pot made of clay. The main ingredients used are a mixture of processed beef, tripe, cow spleen, and beef offal.

It is called empal, because the main ingredient is beef, which is slightly fatty and cooked as tender as the known empal. The affix for the barrel emphasizes that the cooking process uses a large barrel or a large pot made of clay. Maybe that's why this kind of empal uses the nickname of empal gentong. Although now, not all restaurants still use barrels as a processing facility. The cooking process for at least five hours in this barrel or cauldron uses special firewood, namely wood from the tamarind tree, which can create a taste and tender level of the meat, as well as providing an arousing delicious aroma.

Empal gentong is one of the special dishes that must be tasted when you visit Cirebon. A delicious bowl of empal gentong consists of soft meat and rich seasonings, while the composition of the dish can be selected, with only cutlets or mixed with tripe and offal, and served with white rice or lontong that can also be mixed or separated. Empal gentong is better to eat when it is still warm. Of course, like the tongseng and other recipes, the Cirebonese empal gentong is also very suitable to be eaten with crackers and dried chili sauce to add to its taste. The main ingredient of Empal Gentong is beef, which usually uses the type of brisket, enriched with beef offal such as lungs, spleen, and beef liver, and can also use thick coconut milk. The spices used are garlic, shallots, turmeric, coriander, cumin, hazelnut, cinnamon, bay leaves, galangal, ginger, lemongrass, cloves, and cardamom. If needed, add more salt and sugar until you get a taste that really fits the tongue.

The purpose of this research was to discover that culinary can be influenced by culture, not necessarily by its geographic location. The study would only apply to the city of Cirebon with the limitation to empal gentong and its 
influence to the community through the repetition of behaviour that may induce identity to the culinary.

\section{KEY ISSUE}

The culture of Cirebon as a coastal-city environment deserves to have the food that has a peculiarity of the beach. Especially since the livelihood of most of the community is fishermen, catching fish and rebon (small shrimp) along the coast, as well as making shrimp paste, paste, and salt, are the daily jobs of coastal communities in Cirebon city. The question that arises is: Why is the popular food based on and processed from beef such as empal gentong, not from fish?

\section{RESEARCH METHODOLOGY}

The type of research used is descriptive research, using the hermeneutic-phenomenology approach method. This approach is applied to reveal the similarity of meaning which is the essence of a phenomenon that is consciously experienced by individual informants. Personal experience of information sources is directly linked to other data sources, which is carried out through literature studies. The research paradigm used is hermeneutics, which is the method used to interpret the world through text.

The method used was intended so that researchers can develop a literature review and then strengthen it with the results of dialogue reconstruction, explanations of the physical setting, reports of special events, activities - and reflective notes - opportunities for researchers to record personal thoughts such as speculations, feelings, problems, ideas, hunches, impressions, and prejudices, as stated in [2]. Researchers will place themselves fully in a position to determine the completion of interpretation based on inductive thinking patterns.

\section{DISCUSSION}

The city of Cirebon has so many places to eat that serve empal gentong, which is packed with culinary lovers during weekends and holidays. Some of them have even existed decades ago, and cooking skills or gastronomy is growing. Food is the backbone of many traditions, bringing together family and relatives, and friends in the same environment to celebrate certain events and customs. Food and culture are inter-related, mapping identities, origins and what is experienced by society at any given moment. This identity is reflected in preparing meals in the kitchen at home and in the restaurant. The traditions that involve food and their meanings vary between cultures and regions, and represent cultures in terms of survival, friendliness, comfort, and the availability of basic raw materials. Food is chosen - and what is accessible and available - and how it is prepared, served and eaten, is influenced by the past and touched on by culture.

Gastronomy becomes an important attribute in tourism development and destinations. Although the literature supports the view that there is a relationship between tourism and gastronomy, in general it is very rare for tourists to have skills in cooking. This cooking skill intersects in culinary tourism. Culinary tourism refers to the exploration of food and places to eat, especially in places that are considered to be encounters with other foodies.

This encounter with fellow food lovers has the potential to develop the tourism-gastronomic market segment, so that gastronomy contributes to the quality of experience of tourists when visiting tourist destinations. The analysis of travel narratives told by tourists through social media, tells the relationship between food experiences, how to enjoy the food, and the feelings of tourists. [3] highlighted that the experience of tourists enjoying food while visiting this tourist destination is not only about enjoying the food itself, but also at the same time experiencing other cultures, the taste of adventures, adaptability, and openness to other cultures.

On a larger scale, food is an important part of a culture. Traditional cuisine is passed down from one generation to the next as an expression of cultural identity. Migrants bring food from their place of origin wherever they go and cooking traditional food is a way of preserving their culture when they move to new places.

The new places to live are only a mean of providing facilities for migrants to continue making food from their culture. The culture from this place of origin is a symbol of pride for their ethnicity and a way of overcoming the longing for a previous place.

Many migrants open their own restaurants and serve traditional dishes originating from their hometowns. However, in reality they have to accommodate their tastes and adapt to the tastes of their new residence. The taste of hometown cuisine cannot remain exactly the same as the original taste. This may be because some of the ingredients needed to make traditional dishes may not be available in the new locations. In addition, when migrants sell food in a new place, they do not only sell it to people from the same place as them, but also to various other people such as migrants from other places, as well as current residents, who have been in the new place earlier. Thus, its taste must be adapted to the local taste.

This condition makes the taste different from the dishes they prepare based on their place of origin. Therefore, they have to change the original dish to serve more customers with different tastes and taste preferences. Changes to the original dish can create new flavours that still retain the cultural significance of the dish. [4] mentioned that as daily activities, the life-sustaining activity, the experience of eating reveals a complex relationship between food and society, involving not only the material and symbolic aspects of culture and food order, but also the aesthetics or hedonism.

Food orders represent, first of all, the cultural acts expressed through speech and actions. This means that the way a person understands and relates to others can be seen from the way the food is processed and eating practices. These eating practices include using cutlery, chopsticks, and even your fingers. All that is always related to the deepest identity of a person. The interpretation that coincides with this approach, according to [5], is to understand these fundamental dimensions - identity, food, culture - in their 
ontological or essentialist dimension, shifting from the identity to the identification with the best, the ideal in culinary or in gastronomy.

Moreover, [5] explained that food embodies this permanent dialectic between attachment to the original model, to its symbols, or totemic dishes, its recipes, rituals and practices, and, conversely, the need to endlessly explore, seek new tastes, new dishes, new recipes, newly-adapted eating behaviours, and new eating places.

This adaptation to new dining establishments guides the anthropology of food and nutrition in particular, and the study of food in general, which combines cultures, individual lifestyles, including local and global cultures. This condition, according to [6], allows the assimilation of culture and lifestyle, which makes it more likely to embrace the history and geography of food as part of the holistic emphasis of anthropology.

Food plays an important role in shaping individual identity, because it is motivated by cultural roots and even personal beliefs. This cultural background allows food to retain a large number of historical and ethnic roots and serve as important reminders of tradition and identity formation.

This identity is translated into various meanings of food in many ethnic traditions, which link the relationship between food and culture. Food becomes a part of culture that provides great insight into how food also serves as an indicator of ethnic inferiority and superiority.

Over the centuries, various connections between gastronomy and diplomacy have become apparent. Major events involving large numbers of people usually involve using banquets to celebrate or even to get agreement on what wishes were conceived, worked out, and organized together. This provides support that what you think, dream or do, is determined by what you eat and what you drink.

The diversity of the population in a city allows multiculturalism to occur. Multicultural cities have the opportunity for all components of the population to serve and enjoy the food from where they live. Every city dweller has the opportunity to experience different types of culture, history, or identity through different foods. Food ties into this concept perfectly, because when observing different food practices across different cultures, it ignites different themes and messages from other cultures. Food connoisseurs are doing an urgent job to provide evidence for their claim that food and culture are linked to everyday life, especially with regard to the food.

Cirebon as a coastal city that produces and enjoys seafood from the surrounding waters, of course initially will enjoy the seafood seven days a week. Aman (not his real-name) as a generation-to-generation resident of Cirebon, really enjoys prawns, fish, and shellfish, but prefers meat that has a texture and likes a softer and more delicious taste. He prefers soft meat, perfectly cooked, or fried in tamarind and salt, without harsh seasonings, when enjoyed it is enough to add chili paste, a little fresh vegetables, and white rice. Awa (not his real name), who is also a resident of Cirebon, also likes fish but opens up and ventures to enjoy preserved fish and trevally fish. Trevally fish is a type of pindang (preserved-fish with salt without drying), which is the result of processed fish, trout, sardine (tembang), mackerel, by a combination of boiling (cooking) and salting. Trevally fish is usually eaten on days when they are not at the sea, especially when the sea experiences a "west" season, with strong winds and big waves in the sea.

What the coastal residents and fishermen who live and work along the coast of Cirebon enjoy, are more than just a matter of taste. Those who share their favourite food consistently say that the seafood they bring home to eat also really depends on what is in season and what they can catch to take home or trade. They are still very dependent on fishing results. If the fish have high economic value, they will only eat the fish once or twice a week. All these economicallyvaluable fish, which are confirmed to be fresh, and not out of the sea for too long, are usually sold intact to consumers Taste becomes the key word in the formation of a culinary culture. Cirebon which is given the nickname as "The City of Shrimp" presents a variety of cultures according to different individuals who are reflected in their behaviour. Differences in human 'diets' are the result of continuous interactions between human nutritional needs, ecology, and possibly by the availability of food sources and processing materials. This relates to [7], mentioning that the various diet regimes that human beings now have, experience an evolutionary story to tell of the journey from less-calorie and under-nourished food to more nutrient-rich and more calorie-rich foods.

The behaviour in making decisions to determine the typical food choices, can increase positive feelings among those who eat together. A choice of food that optimizes the aromatic elements of a dish, will promote a feeling of togetherness, a feeling of compatibility with one another. What is said about the food served and enjoyed can convey a message about the identity of the rich insights of food processors and connoisseurs of these foods.

This similarity of identity will reveal this kind of approach, that identity is more of an expression of "feelings and stomachs" than "feelings and thoughts." The feeling of being a resident in the border area is not only influenced by the Sundanese and Javanese culture, but also influenced by the culture of the neighbouring countries, who influence the diet of the Cirebonese. Although it has a port, the activities of Cirebon residents are generally influenced by land culture rather than coastal-community culture.

Adi (not his real-name) said that the city of Cirebon before the Dutch occupation was a trading area, mainly because of the existence of a coastal area that had a port. Many migrants from various countries came to visit Cirebon, as a port of call. These immigrants brought their own food culture. One of the most popular (now) named gulai. Gulai is a type of food that contains a rich, spicy, and delicious curry sauce. The main ingredients may be poultry, mutton, beef, various types of offal, and so on, and are cooked in coconut milk.

When the newcomers introduced curry to Cirebon, the people of Cirebon in the mainland were not used to using frying pans and pans for cooking. At that time, Cirebonese was still familiar using the ceramic-based and clay-based facilities. Cirebon, as it is said, has a history related to this ceramic. It can even be said that this ceramic craft has existed since the Neolithic era. At that time, many residents 
had come to the Cirata area along the Citarum river, as evidenced by the excavation of Cirata that found stone tools, axes, including the items made of ceramics. It is proven that the Plered people in the Cirebon area have long been making ceramics, especially since clay, which is used as the main material, is widely available there.

The newcomers who brought food culture in several types of food such as "curry" from their place of origin influenced the people of Cirebon city. The city of Cirebon at that time had food preferences that were strongly influenced by the characteristics of the main royal-food, namely Padjajaran, so that animal-based food besides fish, could also be said that it became normal. The Cirebon people in general could enjoy meat, and food with the main ingredient of meat became part of their daily lives.

At that time, the people of Cirebon were not accustomed to using cooking utensils made of metal, such as pots and pans. When they wanted to try "curry" food, instead of using metal utensils, they used "barrel" (gentong) instead of the cooking pot. The curry adapted from outside cultures and the richness of local culture made the name of the food, Empal Gentong (literally means as beef cooked in a barrel). Centuries later, the empal gentong has been preserved and continues to be preserved by gastronomers and culinary specialists, regarding how to choose the ingredients, process and serve them. Empal Gentong confirms that the history of cultural evolution is also about the food culture.

Generally, a society grows and develops as a product of eating habits and the food it enjoys. The development of human beings demands more nutrients, which makes human dietary patterns varies. Restated by [7], human beings undergo changes and become omnivores, which are combined with rich and easily-digested nutrients through products derived from the plants. All of them are preserved through the food served and marketed by food vendors.

[8] mentioned that food vendors as restaurant owners have an obligation to sell and offer food that will attract customers. Gastronomists and culinary experts have a concern to design the menus and care about serving food that is interesting, flavourful, and still nutritious. They have to offer the food that will attract customers, through the list of dishes on the menu list. The menu is à la carte, there is no way to ensure that the customer will order the items that become a nutritionally-balanced meal. Restaurant owners do have an obligation to offer choices, that is, the menu that must be planned according to customer tastes.

The menus should be planned for people who eat the food. This sounds like a simple rule, but it is often overlooked. Restaurant owners must not forget that customers are the main reason for doing business. They must maintain the consistency of serving the food that the customers like. This preference means that, in most materials, the processing method is tailored to what the customer prefers.

Customers who already feel comfortable in the menus according to their preferences, will become regular customers, and will advocate for the dish as well as the restaurant. Once a customer is satisfied with a meal, the food serving becomes part of the restaurant's identity. The restaurant cooks and managers must be consistent in maintaining it so that the established identity will still be found by loyal customers who come. An identity that may have gone viral is the reason for potential new customers to taste the food. This is evidenced in Empal Gentong Haji Apud, Empal Gentong Amarta, Empal Gentong Bu Darma and so on, which are located on strategic roads in the city of Cirebon which have always been a culinary tourism destination in Cirebon. Empal Gentong is a typical food that is part of Cirebon's culinary culture, and is one of several other reasons for tourists to visit Cirebon.

\section{CONCLUSION}

In Cirebon, harmony is an essential trait in almost every aspect of life. This is reflected in Cirebon cuisine, almost every taste (salty, spicy, sour, sweet, and bitter) is used in a balanced-way to create delicious dishes like those found in the Empal Gentong dish, which is a culinary culture that combines the ingredients derived from natural resources and cooking culture, producing a blend of flavours that suit almost everyone's tongue. Historically, Cirebon people have had their own style of enjoying and processing their food. They believe that food does not only need to be nutritious, but also needs to look attractive, so they go to great lengths to make the dishes attractive, and have an appetizing aroma. Empal Gentong in Cirebon reinforces the notion that every culture has its own peculiarities, and it is important to remember that each dish has a special place for those who prepare it, process it, and enjoy it. Cirebon embraces a cultural heritage to enrich local culture through the food. Food is a gateway into the culture, and it deserves to be treated as such.

Future research on food peculiarities based on its distinctive culture that is part of heritage on any culture in Cirebon may be studied to comprehend the culture of Cirebon City through its culinary aspect.

\section{REFERENCES}

[1] Disbudparpora Kabupaten Cirebon, 2013. Retrieved on 20 October 2019 at 23:45.

[2] Robert C. Bogdan, Sari Knopp Biklen, 2007. Qualitative Research for Education. An Introduction to Theory and Methods $5^{\text {th }}$ edition. Boston, MA: Allyn and Bacon.

[3] Jennie Germann Molz, 2007. Eating Difference: The Cosmopolitan Mobilities of Culinary Tourism. Space and Culture, SAGE Journals. First Published February 1, 2007. DOI: https://doi.org/10.1177/ 1206331206296383.

[4] A. Beardsworth, T. Keil, 1997. Sociology on the Menu. An Invitation to the Study of Food and Society. London and New York: Routledge. 
[5] Jean-Jacques Boutaud, Anda Becuţ, Angelica Marinescu, 2016. Food and culture. Cultural patterns and practices related to food in everyday life.

Introduction. International Review of Social Research 2016; 6(1): 1-3. DOI 10.1515/irsr-2016-0001

[6] Carole Counihan, Penny van Esterik (Eds.), 2013. Food and Culture, A Reader, 3rd edition. New York, NY: Routledge.

[7] Eugene Newton Anderson, 2005. Everyone Eats. Understanding Food and Culture. New York: New York University Press.

[8] Wayne Gisslen, 2011. Professional Cooking $7^{\text {th }}$ edition. Hoboken, New Jersey: John Wiley \& Sons, Inc. 